\title{
Analysing Macro-Poverty Linkages of External Liberalisation: Gaps, Achievements and Alternatives
}

\section{Bernhard G. Gunter, Lance Taylor and Erinç Yeldan*}

\begin{abstract}
CGE modelling has dominated analysis of the impact of external liberalisation on poverty. This article provides a structuralist critique of standard neo-classical CGE models. It highlights five sets of gaps and partial achievements in the modelling of issues affecting the poverty impact of macroeconomic policies: duality and structural rigidities; efficiency gains and quota rents; the investment and savings specification; the nature of public expenditures; and the modelling of financial fragility, risk premia and issues of credibility. It outlines a model that makes it possible to analyse more plausible stories about the impact of both current and capital account liberalisation and questions the realism of existing approaches to ex-ante poverty impact assessment.
\end{abstract}

\section{Introduction}

For many if not most developing countries, external liberalisation has been the overriding theme in economic policy for the past two decades. The details of implementation, such as sequencing and coverage, have varied between countries. However, in broad terms liberalisation has meant the following: the dismantling of policy instruments that regulate and restrict commodity trade - reducing or outright dismantling of the government's capacity to subsidise rural income through price supports and input subsidies; price liberalisation; privatisation of public assets; deregulation of labour markets; movement towards a flexible (and ultimately floating) exchange-rate administration; and finally, on the financial side, deregulation of the financial asset markets, freeing interest rates, and ultimately liberalising the capital account of the balance of payments to enable free capital mobility internationally. Corresponding to these policy shifts, world trade (measured in terms of nominal exports of goods and services) more than tripled from US\$2.3 trillion in 1985 to over US\$7.8 trillion in 2002, inflows of foreign direct investment (FDI) rose more than ten-fold

\footnotetext{
* Bernhard Gunter (b.gunter@afdb.org) is at the African Development Bank, BP 323, 1002 Tunis Belvedère, Tunisia, and was leading the New Rules for Global Finance Coalition's Project on Ex-ante Poverty Impact Assessment of Macroeconomic Policies (EPIAM) at the time of writing this article. Lance Taylor (lance@blacklocust.com) is at the New School University, New York, USA. Erinç Yeldan (yeldane@bilkent.edu.tr) is at Bilkent University, Ankara, Turkey. This is a shortened and merged version of separate papers prepared by the authors for the EPIAM workshop of October 2003. The views expressed here are entirely those of the authors and should not be taken as representing those of any institution mentioned above.

(c) Overseas Development Institute, 2005.

Published by Blackwell Publishing, Oxford OX4 2DQ, UK and 350 Main Street, Malden, MA 02148, USA.
} 
between 1985 and 2002, and inflows of total portfolio investment increased more than five times during the same period (after having dropped sharply in 2000 and 2001). ${ }^{1}$

A huge literature analyses the impact of external liberalisation, especially on growth, and more recently on income distribution and poverty, with computable general equilibrium (CGE) models being the dominant method of analysis. However, there are serious problems with the standard models that cast doubt on their usefulness for drawing conclusions about the impact of external liberalisation on economic structures in general, and on income distribution and poverty in particular. Following this introduction, this article begins with a critical summary of five sets of gaps and partial achievements in the modelling of issues that affect the poverty impact of macroeconomic policies: (i) duality and structural rigidities; (ii) efficiency gains and quota rents; (iii) the investment and savings specification; (iv) the nature of public expenditures; and (v) financial fragility, risk premia, and issues of credibility. ${ }^{2}$ Section 3 is more technical as it refers to a structural 'fix-price/flex-price' model, which it uses to suggest alternative approaches for analysing external liberalisation. The fourth section questions the two key approaches of ex-ante poverty impact assessments, before the last section provides some concluding remarks.

\section{Standard CGE models: a critical summary of gaps and achievements}

\subsection{Duality and structural rigidities}

The development economics literature explicitly recognises the structural bottlenecks and rigidities that are often associated with developing country capitalism. However, the literature likewise recognises that the usual two-sector models cannot distinguish between the different aspects of dualism that are endemic in developing countries. The basic underlying structure of these models consists of a backward sector, i.e., traditional agriculture, and a modern, urban/industrial, sector. What we witness in most parts of the developing world, however, is that, in addition to this rural-urban dichotomy, these countries further suffer from the dichotomy of (i) traditional technologies in informal/marginalised production relations and (ii) modern technologies in more sophisticated institutional structures which encompass both rural/agricultural and urban/industrial activities.

A variety of more recent and sophisticated models try to address some of these problems. For example, Stifel and Thorbecke (2003) build a CGE model to study the effects of trade liberalisation, especially on poverty, with the model specifically applied to the archetypal structure of an African economy, including a large informal rural sector devoted entirely to staple goods production for domestic consumption and a formal sector mainly destined for exports. They explicitly focus on both rural-urban and

1. See Gunter and van der Hoeven (2004) for more details, notably the marginalisation of many developing countries in this ongoing economic globalisation.

2. Gender issues constitute a sixth set of gaps and partial achievements, but are ignored here as they are addressed in detail by Fontana and Rodgers (in this issue). 
intra-group migration using a Harris-Todaro migration module. ${ }^{3}$ They derive a poverty line endogenously using the laboratory characteristics of the CGE framework, which enables endogeneity of prices. They report evidence that trade liberalisation is expected to lower consumption good prices, thereby reducing the incidence of poverty. However, they also caution that the presence of migration in their model corrects for an otherwise over-estimated poverty reduction.

\subsection{The modelling of efficiency gains and quota rents}

Standard CGE model specifications are usually based on neoclassical trade theory and are typically applied to foreign trade issues in one of two variants: Heckscher-Ohlin and Ricardo-Viner (see Box 1). Both Heckscher-Ohlin- and Ricardo-Viner-based CGE models assess trade liberalisation by computing the effects of reducing protection rates (tariffs or tariff-equivalent quotas).

\section{Box 1: Heckscher-Ohlin and Ricardo-Viner trade models}

In Heckscher-Ohlin-based models, both labour and capital are assumed to be readily shiftable among sectors and fully employed. Competition ensures that all sectoral profit rates are equated economy-wide. Based on these assumptions, it can be shown that the saving-investment balance will be satisfied when goods markets clear. International trade is modelled based on comparative advantages, which derive from differences in relative factor endowments across countries and differences in relative factor intensities across industries. The most famous version is the textbook model of 2 factors, 2 goods, and 2 countries, though it may include any numbers of factors, goods, and countries.

In the Ricardo-Viner model, each sector is supposed to have a fixed, nonshiftable capital stock so that profit rates vary independently of one another. Yet, labour is assumed to be readily shiftable between sectors, whereby sectoral labour demand levels respond negatively to increases in real product wages to clear the labour market. The Ricardo-Viner model is named after two economists (David Ricardo and Jacob Viner) who, among many others, used this specification as the standard model of trade prior to the Heckscher-Ohlin model. It was revived in the early 1970s.

The main finding of most standard CGE studies is that, in the absence of explicit modelling of externalities or other jump-starters, liberalisation does not matter very much for resource allocation. There is some shuffling of output and employment between sectors, going in more or less predictable directions, but the numerical magnitudes originating from such shifts are found to be quite modest in macro terms, with relatively small welfare gains. Based on the static gains of re-allocation of

3. Originally attributed to Harris and Todaro (1970), the Harris-Todaro migration module explains the persistence of rural to urban migration in the presence of widespread urban unemployment by replacing the equality of wages with the equality of expected wages as the basic equilibrium condition in a segmented, but homogenous, labour market. 
resources, the so-called Harberger triangles ${ }^{4}$ often imply gains of less than $1 \%$ of the GDP.

These findings reiterate Rodriguez and Rodrik's (1999) caution that returns to trade reform - to the degree that they materialise - might be related to improved macroeconomic prices (such as the real interest rate and the exchange rate, in contrast to microeconomic relative price adjustments) and institutional innovations. Furthermore, these findings also suggest that any gains from trade liberalisation are often associated with external effects that are dynamic in nature. Such effects were captured in models that incorporate:

(i) the technology content of capital goods imports, see, for example, de Melo and Robinson (1992),

(ii) the elimination of oligopolistic mark-ups, see, for example, Mercenier and Yeldan (1997), and

(iii) research and development (R\&D)-driven technological advances à la Romer (1990), see, for example, Diao et al. (1999).

The CGE folklore has long encompassed modelling of quota rents and the distortionary impacts of tariff and non-tariff barriers, starting with the original DervisRobinson (1978) model. Dervis and Robinson (1978) and Dervis, de Melo and Robinson (1982) explicitly model the distortionary effects of quota rents as direct unproductive rent-seeking, based on the earlier work of Krueger (1974). In such formulations, opportunities for rent-seeking serve as a direct mechanism for worsening income distribution. With their access to import licences, urban producers can capture windfall gains at the expense of non-traded sectors and final consumers. Thus, under such conditions, the elimination of non-tariff barriers tends to produce second-best gains, as well as a lower incidence of poverty.

In a more recent model, Dorosh and Sahn (2000) take a similar approach to study the effects of trade and exchange-rate liberalisation on real incomes of poor households in sub-Saharan Africa. They find that trade liberalisation tends to benefit poor households in both rural and urban sectors, as rents on foreign exchange are eliminated, by increasing demand for labour and rising returns to agriculture. Another channel in their model is that decreases in public deficits (in return to a tax and expenditure reform) tend to increase public savings and invigorate private investments. However, this route produces less certain outcomes for poor people. On the one hand, decreased public expenditures deprive rural and urban poor people of urgently needed flows of public services. This is expected to be offset by the tendency of private investments to rise. This dilemma necessitates a careful and realistic modelling of private investment and savings behaviour.

\subsection{The investment and savings specification}

In most standard CGE models, macro closures often render investments savings-driven and passive, whereby the underlying modelling of the savings specification in the social accounting matrix (SAM) is often based on ad hoc assumptions of macroeconomic

4. See, for example, Agénor (2000: 556) for a recent formal definition of the so-called Harberger triangles. 
closure rules that seem inappropriate for reflecting the realities of developing countries. There are four main cases of modelling the savings specification:

(i) The traditional way is to model private savings as a function of wage and profit income, with the savings rate from profit income either (a) higher than the savings rate from wage income (the Kalecki-Kaldor specification), ${ }^{5}$ or (b) equal to the savings rate from wage income (the Keynesian specification).

(ii) In a second specification, savings may come only from wages in the rather peculiar fashion of an overlapping-generations growth model.

(iii) Third, based on contemporary versions of Ramsey's optimal savings model, ${ }^{6}$ private savings may be determined by infinite horizon intertemporal arbitrage. This is even more peculiar, as it is palpable nonsense to assume that most developing economies have successfully maximised an intertemporal welfare integral à la Ramsey through smooth and well-behaved functional forms over recent periods, even if measured in decades.

(iv) Finally, standard CGE models have treated private savings as a purely endogenous variable that floats to satisfy the adding-up requirement in the underlying social accounting matrix.

While it is convenient to treat private savings as a purely endogenous variable, what is often overlooked or ignored is that such a specification deactivates much of the distributive or output response to changes in effective demand. There is no shortage of structuralist models that specify the savings-investment balance more appropriately; however, these models have (at least until recently) been in the minority. Fortunately, awareness of the importance of a proper savings-investment specification and its closure rule seems to be growing. For example, of the 16 recent country studies analysing the impact of export promotions and trade liberalisations on Latin America's poor (see Ganuza et al., in this issue), ten studies assumed a Keynesian investment-driven closure rule.

\subsection{The nature of public expenditures}

The savings-driven and passive investment specification gives rise to another important gap in addressing the crowding-in attributes of public expenditures. Neoclassical theory often treats public expenditure in a vacuum, providing no direct utility to the private agents. Many CGE models take this specification as given, and treat the government sector at best as a neutral agent supplying and demanding funds and scarce resources for the provision of a public services sector. Yet, that public spending is likely to generate positive externalities is well recognised in the literature. The most influential work along these lines includes Lucas (1988) and Barro (1990). In Lucas (1988), positive externalities of public spending result from the provision of human capital. In Barro (1990), positive externalities of public spending are due to key strategic capital and infrastructure.

5. See Kalecki (1954) and Kaldor (1956).

6. See Srinivasan (1964) for the first modern version, building on Ramsey (1928). 
Drawing on these insights, Jung and Thorbecke (2003) devised a recent model to study the impact of public education expenditure on human capital and the supply of different labour skills, and distributional consequences in Tanzania and Zambia. They argue that education expenditures can raise economic growth, but they also caution that achieving this outcome may require a high level of physical investments. Fougère and Mérette (1999) and Voyvoda and Yeldan (2003) use a similar mapping function from public expenditures on education to the creation of human capital, and study the detrimental consequences of reduced efficiency of public education for long-term growth. All these models suggest that there are positive externalities to public spending that the standard theory fails to capture, and that a more realistic depiction of publicprivate expenditure flows is indispensable for a careful analysis of the poverty impact of fiscal reforms.

\subsection{Modelling financial fragility, risk premia, and issues of credibility}

While interest-rate and exchange-rate movements have played a crucial role in realworld liberalisations, trade models say nothing about the interest rate. Nor do their implications regarding exchange-rate administration provide much guidance. The Ricardo-Viner model offers some room for the exchange rate to have an effect, but its implicit assumption that import liberalisations are supposed to push the economy in the direction of being export-led has received only weak empirical support. The crucial issue is that observed exchange-rate interactions with the real economy inevitably depend on developments in the capital market, especially under liberalisation. Both the Heckscher-Ohlin and Ricardo-Viner specifications (and their numerous real side extensions) ignore this aspect of macroeconomics, and that is the main reason why they do not tell us very much.

With the recent wave of financial liberalisation and increased capital mobility, issues of financial fragility, hedging of uncovered risk premia, and overall credibility have gained importance. Models of the neoclassical genre work with well-behaved, smooth functional forms and often fail to capture sudden and unexpected breaks of shallow financial structures. Adelman and Yeldan (2000) provide a recent exception to this limitation; they utilise an intertemporal optimisation framework, perfect intermediation of a competitive banking system, and efficient and competitive factor and commodity markets with perfect foresight. In their framework, the late 1990s' Asian financial crisis was generated endogenously by a single trigger: an increase in the risk premium against the unprecedented rise of the current account deficit and foreign indebtedness. In turn, the rising deficit and foreign indebtedness were themselves due to large inflows of foreign capital lured by high growth in productivity.

Even though the Adelman and Yeldan model addresses much of the fragility phenomenon associated with immature capital account liberalisation across the developing world, their specification nevertheless fails to capture the impact of interest rates on portfolio choices and the supply side of the credit market. Such innovations are incorporated in other recent modelling exercises, such as those of Agénor et al. (2003 and 2004) for Brazil and Turkey, respectively. These models provide a detailed 
financial structure, along with a direct mapping onto household income distribution and poverty incidences.

\section{Alternative approaches}

In practice, external liberalisation has had strong differential effects on prices and quantities in different sectors of the economy. One way to think about these differential effects is in terms of a 'fix-price/flex-price' model, whereby the fix-price sector corresponds to the tradeable goods sector and the flex-price sector to the non-tradeable goods sector. Such an approach has not been implemented as a CGE model, though it would be straightforward to do so. Box 2 shows the technical details. We concentrate here on a graphical illustration of the model provided in Figure 1.

\section{Box 2: Basic features of a structuralist 'fix-price/flex-price' model}

The key characteristics of a model with a 'fix-price' traded goods sector and a 'flexprice' non-traded goods sector stem from a variety of market imperfections and rigidities. First, goods are produced under imperfect competition. Second, skilled labour and physical capital are fixed factors in the short run.

The simplest formulation involves a discriminating monopolist who manufactures goods that are sold domestically as well as in the export sector. Prior to liberalisation, the monopolist has established mark-up rates over variable costs in both of his/her markets, whereby the levels of the mark-up will depend on the relevant elasticities. Variable costs are determined by market prices and productivity levels of unskilled labour and intermediate imports.

Prices and output in the traded goods market: The traded goods price level $\left(P_{t}\right)$ follows from the domestic mark-up over variable cost. With stable mark-up rates, traded goods comprise a 'fix-price' sector, with a level of output determined by effective demand.

Prices and output in the non-traded goods market: Output of non-traded goods is also determined by demand, and their production is usually intensive in unskilled labour. It is assumed that the non-traded goods sector exhibits decreasing returns to labour in the short run. Higher production results from greater unskilled employment (or labour demand). However, cost-minimising producers will hire extra workers only at a lower real product wage. In other words, a higher price-wage ratio $\left(P_{n} / W\right)$ is associated with greater non-traded goods production, greater employment, and reduced labour productivity (due to the assumed decreasing returns). Without further rigidities, the price-wage ratio $\left(P_{n} / W\right)$ is free to vary, and non-traded goods comprise a 'flex-price' sector.

Figure 1 shows four typical quadrants (i.e., they have each one vertical and one horizontal axis) and one additional irregular quadrant in the extreme southeast, which shares its horizontal axis (denoted as 'Traded goods output $\left.\left(X_{t}\right)^{\prime}\right)$ with the southeast quadrant. The irregular quadrant reflects the trade deficit (as its vertical axis indicates). The arrows adjacent to the lines indicate how the lines shift after current and capital account liberalisations. 
The important implication of this model is that, with stable mark-up rates in the traded goods sector, the inter-sectoral price ratio $\left(P_{t} / P_{n}\right)$ will fall as the price-wage ratio $\left(P_{n} / W\right)$ rises. This implies that a rising price of non-traded goods $\left(P_{n}\right)$ is associated with a real exchange-rate appreciation.?

\section{Figure 1: Initial equilibrium positions in traded and non-traded goods markets and probable shifts after current and capital account liberalisation}

\section{NW}

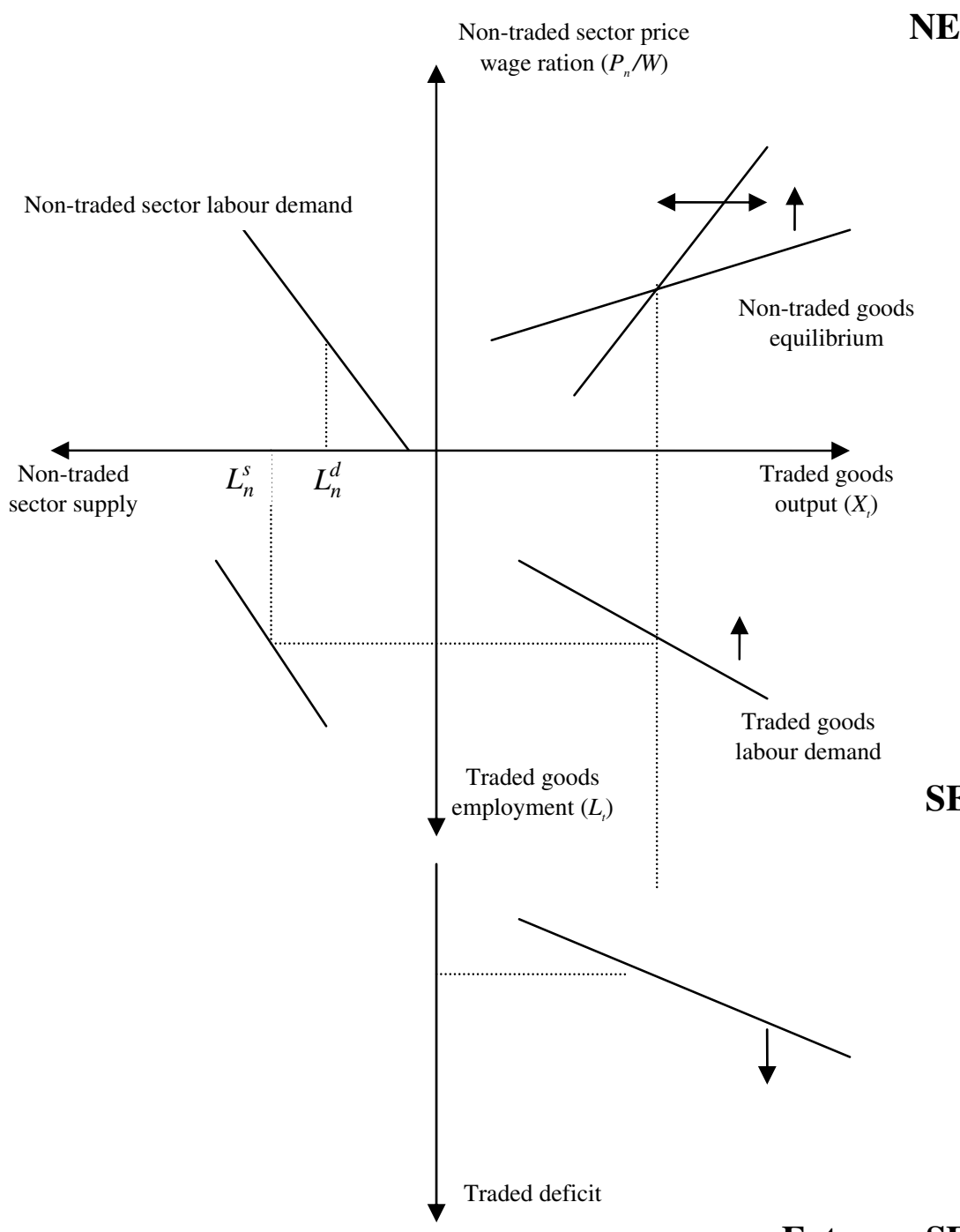

\section{Extreme SE}

7. See the original contribution by Hicks (1965) and subsequent elaborations by Taylor (1990, 1991, and 2004) for more detailed descriptions of the model. 
The key quadrant lies in the northeast (NE). It shows how prices and outputs are determined in the two (non-tradeable and tradeable) sectors. Hence, it shows two upward sloping lines, reflecting the 'Traded goods equilibrium' and the 'Non-traded goods equilibrium'.

\section{Traded goods equilibrium}

The way the schedule for the traded goods equilibrium is drawn assumes that demand for traded goods output $\left(X_{t}\right)$ is stimulated by an increase in the non-traded price wage ratio $\left(P_{n} / W\right){ }^{8}$

\section{Non-traded goods equilibrium}

Along the schedule for the non-traded goods equilibrium, a higher traded goods output level (denoted by $X_{t}$ ) is assumed to generate additional demand for non-traded goods. As the additional demand is met by an increase in the supply of non-traded goods, the non-traded price-wage ratio (denoted by $P_{n} / W$ ) will rise.

The combination of the traded and non-trade goods equilibria constitutes the shortrun macro equilibrium, which - as drawn in Figure 1 - is stable. ' This macro equilibrium helps determine the status of several markets in the economy. For example, unskilled labour demand in the non-traded sector $\left(L_{n}^{d}\right)$ is determined in the northwest (NW) quadrant. Employment in the traded goods sector is shown in the southeast (SE) quadrant. A lower employment level in traded goods liberates labour that can be used in the other sector, as shown in the southwest (SW) quadrant. As the diagram is drawn, labour supply $\left(L_{n}^{s}\right)$ exceeds demand $\left(L_{n}^{d}\right)$ in the non-traded sector, i.e. there is open or disguised unemployment as measured by the difference $\left(L_{n}^{s}-L_{n}^{d}\right)$. Finally, in the extreme southeast (extreme SE) quadrant, bigger trade deficits are associated with higher levels of the traded goods output level $\left(\mathrm{X}_{\mathrm{t}}\right)$ and higher levels of the non-traded price-wage ratio $\left(P_{n} / W\right)$.

As indicated above, many developing countries liberalised both the current and capital accounts almost simultaneously in the late 1980s or early 1990s. Given this history, one has to consider the two policy shifts together. However, for analytical clarity it is useful to dissect them, as is done in the less technical stories provided in the next two sub-sections.

\subsection{Current account liberalisation}

Current account deregulation in developing countries basically took the form of transformation of import quota restrictions (where they were important) to tariffs, and then consolidation of tariff rates into a fairly narrow band, for example, between zero and $20 \%$. With a few exceptions, developing countries also removed export subsidies. There were visible effects on the level and composition of effective demand, and on

8. It should be pointed out that, depending on income effects, a higher level of the non-traded price wage ratio $\left(P_{n} / W\right)$ can be associated with either higher or lower demand for traded goods output $\left(X_{t}\right)$, while the way the schedule is drawn above illustrates the former case.

9. A stable equilibrium implies that market forces work towards reaching a new equilibrium should any shock disturb the current equilibrium. 
patterns of employment and labour productivity. Demand composition typically shifted in the direction of imports, especially when there was real exchange-rate appreciation. In many cases, national savings rates also declined. An increased supply of imports at low prices (increasing household spending, aided by credit expansion following financial liberalisation) provides part of the explanation for the shift. It also resulted from a profit squeeze (falling retained earnings) in industries producing traded goods. The fall at times in private savings was partially offset by rising government savings where fiscal policy became more restrictive. Many countries showed 'stop-go' cycles in government tax and spending behaviour.

Especially when current account liberalisation went together with real appreciation, this pushed traded goods producers towards workplace reorganisation (including greater reliance on foreign outsourcing) and downsizing (which would be reflected by an upward shift of the traded goods labour demand curve in the SE quadrant of Figure 1). If, as assumed above, unskilled labour were an important component of variable cost, then such workers would bear the brunt of the adjustments via job losses. In other words, traded goods enterprises that stayed in operation had to cut costs by generating growth in labour productivity. Depending on demand conditions, their total employment levels could easily fall.

The upshot of these effects often took the form of increased inequality between groups of workers, in particular between the skilled and unskilled. This outcome is at odds with widely discussed predictions of the Stolper-Samuelson theorem based on the Heckscher-Ohlin model, ${ }^{10}$ according to which trade liberalisation should lead to an increase in the remuneration of the relatively abundant production factor in low- and middle-income countries (unskilled labour) with respect to the scarce factor (capital or skilled labour). The model illustrated in Figure 1 more closely resembles the RicardoViner than the Heckscher-Ohlin framework by working with more than two production factors and allowing for open unemployment, factor immobility, and product market imperfections. These considerations, along with changes in the sectoral composition of output, are important factors in determining the distributive effects of trade liberalisation. With liberalisation stimulating productivity increases and leading to a reduction of labour demand from traded-goods production, primary income differentials widened between workers in such sectors and those employed in non-traded, informal activities (for example, informal services) and the unemployed.

\subsection{Capital account liberalisation}

Countries liberalised their capital accounts for several apparent reasons - to accommodate to external political pressures (Korea and many others), to find sources of finance for growing fiscal deficits (Turkey and Russia), or to bring in foreign exchange to finance the imports needed to hold down prices of traded goods under exchange-ratebased inflation stabilisation programmes (Argentina and Mexico). Whatever the rationale, when they removed restrictions on capital movements, most countries

10. See Stolper and Samuelson (1941). The basic idea of the Heckscher-Ohlin model is that a country in which labour, for example, is relatively abundant (compared with other countries) will produce the labourintensive good relatively cheaply; and will thus have a comparative advantage in the production of that good. 
received a surge of inflows from abroad. The new assets typically showed up on the balance sheets of financial institutions, including larger international reserves of the central bank. Unless the central bank made a concerted effort to 'sterilise' the inflows (for example, by selling government bonds from its portfolio to absorb the extra liquidity), they set off a domestic credit boom.

Due to underdeveloped and poorly regulated financial markets, this credit boom many times had two negative implications. First, it carried a high risk of resulting in a classic Kindlebergian mania-panic-crash sequence (see Kindleberger, 1996). The famous crises in Latin America's Southern Cone around 1980 were only the first of many such disasters. Second, credit booms ended up pushing the spread between borrowing and lending rates upwards, largely due to the combination of three reasons:

(i) asset price booms in housing and stock markets forced rates to rise on interestbearing securities such as government debt;

(ii) central banks trying to sterilise capital inflows pushed up interest rates as well; and

(iii) non-competitive financial institutions often found it easy to raise spreads.

Unsurprisingly, exchange-rate movements complicated the story. In many countries, the exchange rate was used as a 'nominal anchor' in anti-inflation programmes. Yet, the nominal exchange rate was usually devalued at a rate lower than the rate of inflation, leading to a real appreciation. In several cases, the effect was rapid, with the variable costs of traded goods in dollar terms jumping upwards immediately after the exchange rate was frozen. Again, this would be reflected by an upward shift of the traded goods labour demand curve in the SE quadrant of Figure 1 and corresponding shifts in the other quadrants as indicated by the arrows.

In conclusion, capital account liberalisation combined with a boom in external inflows could easily provoke 'excessive' credit expansion. Paradoxically, the credit boom could be associated with relatively high interest rates and a strong local currency. These were not the most secure foundations for liberalisation of the current account.

\section{Modelling distribution and poverty}

Suppose we put together a model based on Figure 1 and incorporating the partial modelling achievements described in Section 2. What could it say about poverty? Two approaches to ex-ante poverty impact assessments show up in the literature. One approach is to use a 'poverty equation' with the headcount ratio (or something similar) as its dependent variable and macro outcome indicators such as per capita GDP, the inflation rate, the output growth rate, the real exchange rate, etc. as explanatory variables. Projections of these macro outcomes presumably emerge as functions of policy changes from some sort of CGE model. Yet, whether a plausible poverty equation can be estimated from (typically) short time series in any given developing country is an open question.

The other approach is to 'map' the sectoral-functional income distribution produced by a CGE simulation into the size distribution. In effect, the price and quantity changes emerging from the simulation are assumed to modify household income flows in well-determined ways. For example, households in a given decile may, on average, receive a certain fraction of wage income generated within each of the model's sectors, 
plus a certain fraction of proprietors' incomes (if they are considered), interest payments, and distributed profits, etc. If unemployment rises, the household incomes of the unemployed (assuming they do not have significant other incomes that could compensate for the loss in wage income, as is frequently the case), would need to be reduced accordingly. Finding information to generate such a mapping is by no means a trivial task. Household income-expenditure surveys and labour-market surveys may provide a start but by no means a finish, and there are not many other data sources to turn to. Hence, as with the creation of a basic SAM for a CGE exercise, both imagination and perspiration are required to manufacture the data. One hopes that a modicum of reality can also enter in.

\section{Concluding remarks}

The effects of macro-level changes on distribution and poverty are bound to be complicated, especially in developing countries. First, in any sensible analysis for developing countries Engel effects in demand (i.e., the proportions of the household budget spent on basic consumption goods declines as income rises) will matter macroeconomically. Second, standard models typically presuppose full employment of labour and (often) capital, presumably because these conditions are supposed to apply in the long run. Yet, this 'long run' is at best a logical construct, since over periods of decades full employment is not observed in most poor countries, especially those where the International Monetary Fund is more or less permanently encamped in the capital, applying its contractionary conditionalities. Third, models that focus solely on the real side of the economy cannot cope with the financial aspects of liberalisation, meaning that whatever they have to say about distribution is necessarily questionable.

\section{References}

Adelman, Irma and Yeldan, Erinç (2000) 'The Minimal Conditions for a Financial Crisis: A Multiregional Intertemporal CGE Model of the Asian Crisis', World Development 28 (6): 1087-100.

Agénor, Pierre-Richard (2000) The Economics of Adjustment and Growth. San Diego, CA: Academic Press.

Agénor, Pierre-Richard; Tarp Jensen, Henning; Verghis, Mathew and Yeldan, Erinç (2004) 'Disinflation, Fiscal Sustainability, and Labor Market Adjustment in Turkey'. Washington, DC: World Bank, July (mimeo).

Agénor, Pierre-Richard; Fernandes, Reynaldo; Haddad, Eduardo and van der Mensbrugghe, Dominique (2003) 'Analyzing the Impact of Adjustment Policies on the Poor: An IMMPA Framework for Brazil'. Washington, DC: World Bank (mimeo) (available at http://www.ecomod.net/conferences/ecomod2003/ecomod 2003_papersHaddad-IMMPA.pdf).

Barro, Robert J. (1990) 'Government Spending in a Simple Model of Endogenous Growth', Journal of Political Economy 98 (5): 103-25.

de Melo, Jaime and Robinson, Sherman (1992) 'Productivity and Externalities: Models of Export-led Growth', Journal of International Trade and Economic Development 1 (1): 41-68. 
Dervis, Kemal and Robinson, Sherman (1978) The Foreign Exchange Gap Growth and Industrial Strategy in Turkey: 1973-1983. World Bank Staff Working Paper No. 306. Washington, DC: World Bank.

Dervis, Kemal; de Melo, Jaime and Robinson, Sherman (1982) General Equilibrium Models for Development Policy. Cambridge: Cambridge University Press.

Diao, Xinshen; Roe, Terry and Yeldan, Erinç (1999) 'Strategic Policies and Growth: An Applied Model of R\&D-Driven Endogenous Growth', Journal of Development Economics 60 (2): 343-80.

Dorosh, Paul A. and Sahn, David E. (2000) 'A General Equilibrium Analysis of the Effect of Macroeconomic Adjustment on Poverty in Africa', Journal of Policy Modeling 22 (6): 753-76.

Fougère, Maxime and Mérette, Marcel (1999) 'Population Ageing and Economic Growth in Seven OECD Countries', Economic Modeling 16 (3): 411-27.

Gunter, Bernhard G. and van der Hoeven, Rolph (2004) 'The Social Dimension of Globalization: A Review of the Literature', International Labour Review 143 (12): 7-43.

Harris, John R. and Todaro, Michael P. (1970) 'Migration, Unemployment and Development: A Two-Sector Analysis', American Economic Review 60 (1): 12642.

Hicks, John R. (1965) Capital and Growth. Oxford: Clarendon Press.

Jung, Hong-Sang and Thorbecke, Erik (2001) The Impact of Public Education Expenditure on Human Capital, Growth, and Poverty in Tanzania and Zambia: A General Equilibrium Approach. IMF Working Paper WP/01/106. Washington, DC: IMF, August.

Kaldor, Nicholas (1956) 'Alternative Theories of Distribution', Review of Economic Studies 23 (2): 83-100.

Kalecki, Michal (1954) Theory of Economic Dynamics: An Essay on Cyclical and Long-Run Changes in a Capitalist Economy. London: Allen and Unwin.

Kindleberger, Charles P. (1996) Manias, Panics and Crashes. 3rd edn. New York: John Wiley and Sons.

Krueger, Anne O. (1974) 'The Political Economy of the Rent-Seeking Society', American Economic Review 64 (3): 291-303.

Lucas, Robert E. Jr. (1988) 'On the Mechanics of Economic Development', Journal of Monetary Economics 22 (1): 3-42.

Mercenier, Jean and Yeldan, Erinç (1997) 'On Turkey's Trade Policy: Is a Customs Union with Europe Enough?', European Economic Review 41 (3-5): 871-80.

Ramsey, Frank P. (1928) 'A Mathematical Theory of Saving', Economic Journal 38 (4): 543-59.

Rodriguez, Francisco and Rodrik, Dani (1999) Trade Policy and Economic Growth: A Skeptic's Guide to the Cross-National Evidence. Working Paper Series No 7081. Cambridge, MA: National Bureau of Economic Research, April.

Romer, Paul M. (1990) 'Endogenous Technological Change', Journal of Political Economy 98 (5): S71-102.

Srinivasan, T. N. (1964) 'Optimal Savings in a Two Sector Model of Growth', Econometrica 32 (3): 358-73.

Stifel, David C. and Thorbecke, Erik (2003) 'A Dual-Dual CGE Model of an Archetype African Economy’, Journal of Policy Modeling 25 (3): 207-35. 
Stolper, Wolfgang F. and Samuelson, Paul A. (1941) 'Protection and Real Wages', Review of Economic Studies 9 (1): 58-73.

Taylor, Lance (1990) 'Structuralist CGE Models', in Lance Taylor (ed.), Socially Relevant Policy Analysis. Cambridge, MA: MIT Press.

Taylor, Lance (1991) Income Distribution, Inflation, and Growth: Lectures on Structuralist Macroeconomic Theory. Cambridge, MA: MIT Press.

Taylor, Lance (2004) Reconstructing Macroeconomics. Cambridge, MA: Harvard University Press.

Voyvoda, Ebru and Yeldan, Erinç (2003) 'Managing Turkish Debt: An OLG Investigation of the IMF's Fiscal Programming Model for Turkey', Comparative Economic System (available at http://www.bilkent.edu.tr/ yeldane/V\&Y JPM2003-3.pdf). 